\title{
Impact of ultraviolet-B radiation on growth and biochemical composition of Botryococcus braunii Kutz.
}

\author{
Chidambaram Kurinjimalar*, Ganapathy Kavitha, Rangaraja Thevanathan, \\ Govindaswamy Kulandaivelu and Ramasamy Rengasamy
}

Centre for Advanced Studies in Botany, University of Madras, Guindy Campus, Chennai 600 025, India

\begin{abstract}
The present study examines the impact of ultravioletB (UV-B) radiation stress on commercially significant microalga for biofuel application. Experimental alga Botryococcus braunii was treated under different doses of artificially enhanced UV-B radiation. The organism was treated under high dose rates of 1 and $5 \mathrm{Wm}^{-2}$ with altered time durations of $15,30,45$ and $60 \mathrm{~min}$. It showed large variations in the growth characteristics analysed. The rate of whole-cell photosynthetic oxygen evolution showed steep drop in high dose compared to low dose-treated cultures. As a result, level of photosynthetic pigment chlorophyll $a$ content decreased drastically while carotenoid level invariably increased. Consequently, the level of primary metabolites such as total carbohydrate, protein and lipid was drastically reduced under high dose while marginal decrement was observed at lowest dose of UV-B radiation. Overall, the impact of UV-B radiation on $B$. braunii led to a drop in protective mechanisms with associated decline in growth and cellular imbalance at high intensity studied.
\end{abstract}

Keywords: Botryococcus braunii, chlorophyll a, oxygen evolution, ultraviolet-B radiation.

As primary producers, microalgae are the basic unit of the food chain, dominating both aquatic and terrestrial ecosystems. They account for about $60 \%$ of oxygen production, which is ultimately reducing to $50 \% \mathrm{CO}_{2}$ via carbon fixation ${ }^{1}$. In recent years, significant changes have been observed in the aquatic ecosystem owing to increased solar ultraviolet-B (UV-B) radiation penetrating the earth's surface. This is due to increased reduction of stratospheric ozone layer as a result of adverse anthropogenic activities. The undesirable effects of UV-B radiation on photosynthetic microalgae could also affect the next trophic level and can have far-reaching

\footnotetext{
*For correspondence. (e-mail: cskurinjimalar@gmail.com)
}

consequences as they form the basis of the food chain ${ }^{2}$. In general, high rate of UV-B radiation is known to have a negative impact on living organisms, starting at the molecular, cellular and ultimately population level ${ }^{3}$.

The process which is predominantly affected by UV-B radiation is photosynthetic reaction, which leads to damaging effects ${ }^{4}$. However, photosynthetic organisms depend on solar energy containing damaging UV radiation for their photosynthetic process. This non-ionizing UV radiation is found to be $8-9 \%$ of the total earth surface reaching radiation ${ }^{5,6}$. Of the total non-ionizing radiation, only $1.5 \%$ is constituted by UV-B radiation (280-320 $\mathrm{nm})$ reaching the earth surface having direct damaging affects on both aquatic and terrestrial biota ${ }^{7}$. Decreasing stratospheric ozone layer highly increases UV-B penetration into the earth's atmosphere. This harmful abiotic stress affects all forms of life starting from the lowest-level of living organisms in trophic level, i.e. microalgae. This vulnerability is exerted in photosynthesis, growth and eventually in survival as well, due to the necessity of solar energy for photosynthetic process. UV-B radiation can alter cellular morphology, motility and DNA damages which eventually exert in reduced biomass production $^{8-10}$.

The penetration of UV-B radiation is found to be high in tropical regions than temperate regions ${ }^{11,12}$. Several studies have reported the impact of UV-B radiation on plant growth pattern and productivity. However, studies pertaining to the influence of UV-B radiation on growth and physiological activities of colonial green microalga Botryococcus braunii at high dose are lacking. Therefore, $B$. braunii, a renewable source of biomass and hydrocarbons was chosen for this study ${ }^{13,14}$. B. braunii grown under outdoor conditions in raceway ponds showed good growth with biomass yield of $1.5 \mathrm{~g} \mathrm{l}^{-1}$ and $30 \%$ hydrocarbon content $\mathrm{t}^{15}$. Besides biofuel applications, B. braunii contains $79-84 \%$ lutein of total carotenoids which could be exploited for pharmaceutical applications ${ }^{16}$. In this article, we report the effect of short-term and high-dose artificial UV-B radiation on growth and physiological activities of B. braunii. 


\section{Materials and methods}

\section{Culture and growth conditions}

B. braunii was obtained from Algal Culture Collection, Centre for Advanced Studies in Botany, Guindy campus, University of Madras, Chennai. It was cultured photoautotrophically using Modified Chu-13 medium ${ }^{17}$ and grown at $25 \pm 2{ }^{\circ} \mathrm{C}$ with $12: 12 \mathrm{~h}$ light-dark photoperiod conditions.

\section{Different doses of $U V-B$ intensities and durations on B. braunii}

The $B$. braunii culture was treated at different intensities ( 1 and $5 \mathrm{Wm}^{-2}$ ) of UV-B radiation for different durations $(15,30,45$ and $60 \mathrm{~min})$. The UV-B treated cultures were kept under dark for 15 min (ref. 18); then transferred to fresh medium and growth parameters recorded for a period of 18 days at a regular time interval of 3 days.

\section{Photosynthetic oxygen evolution measurement}

Photosynthetic oxygen evolution of the experimental culture was monitored for a period of $5 \mathrm{~min}$ at an interval of $30 \mathrm{sec}$ at $25^{\circ} \mathrm{C}$ using YSI biological oxygen electrode, immediately after UV-B treatment. Saturating white light $\left(200 \mathrm{Wm}^{-2}\right.$ ) was passed through $1 \% \mathrm{CuSO}_{4}$ filter solution which acts as a heat filter. Two millilitre of cells containing $30-40 \mu \mathrm{g} \mathrm{ml}^{-1}$ of chlorophyll $a$ was used for estimation of oxygen evolution.

\section{Specific growth rate analysis}

The number of generations per unit time in an exponentially growing culture was determined following standard method $^{19}$.

\section{Biomass estimation}

To determine the yield of dry biomass, $30 \mathrm{ml}$ culture was filtered through $\mathrm{GF} / \mathrm{C}$ filter. The filtered biomass was oven-dried at $60^{\circ} \mathrm{C}$ till constant weight was obtained; it was then weighed gravimetrically. The dried biomass of $B$. braunii was expressed in $\mathrm{g}^{-1}$ dry wt.

\section{Photosynthetic pigments estimation}

Photosynthetic pigments were estimated spectrophotometrically in $100 \%$ acetone $^{20}$.
Chlorophyll $a\left(\mathrm{mg} \mathrm{l}^{-1}\right)=11.24 \times \mathrm{A}_{661.6}-2.404 \times A_{644.8}$.

Total carotenoid $\left(\mathrm{mg} \mathrm{l}^{-1}\right)$

$$
=\frac{\left(1000 \times A_{470}-1.9 \times \mathrm{Chl} a-63.14 \times \mathrm{Chl} b\right)}{214},
$$

where $A_{661.6}$ is the absorbance at $662 \mathrm{~nm}, A_{644.8}$ the absorbance at $645 \mathrm{~nm}$ and $A_{470}$ is the absorbance at $470 \mathrm{~nm}$. The values are expressed in $\mathrm{mg}^{-1}$.

\section{Total carbohydrate, protein and lipid estimation}

Total carbohydrate and protein were estimated from $B$. braunii biomass according to the methods of Dubois ${ }^{21}$ and Bradford ${ }^{22}$ respectively. For estimation of total lipid, Folch method was followed ${ }^{23}$.

\section{Tolerance and $L D_{50}$ value determination}

The measure of toxicity as lethal dose ${ }_{50}\left(\mathrm{LD}_{50}\right)$ value of UV-B radiation towards $B$. braunii was calculated based on $50 \%$ reduction in chlorophyll $a$ content compared to control.

\section{Statistical analysis}

Data were analysed statistically and results expressed as mean \pm SEM.

\section{Results and discussion}

Global warming directly influences ozone layer depletion, which eventually results in increasing UV radiation penetration having far-reaching impacts on living biota. This especially affects the primary producer microalgae that form the basic unit of food webs in aquatic ecosystems. Hence there is a need to focus research at this micro level to find the harmful effects of UV-B radiation. This has to be addressed for the benefit of mankind to reduce the negative influential activities made by human being. $B$. braunii is reported to contain maximum lipid, hydrocarbon and carbohydrate content of $19 \%, 11 \%$ and $33 \%$ respectively, which could be resourcefully exploited for various commercial applications ${ }^{24}$; especially Botryococcus sp. having prospective applications from food to biodiesel feed stock ${ }^{25}$. The hydrocarbons produced by B. braunii isolates were reported to be saturated hydrocarbons ${ }^{26}$. Hence the present study is aimed to focus on the effect of UV-B radiation stress on growth and photosynthetic activities of $B$. braunii.

\section{$U V-B$ radiation and photosynthetic oxygen evolution}

Table 1 and Figure 1 show photosynthetic oxygen evolution recorded immediately after UV-B treatment in 
RESEARCH ARTICLES

Table 1. Changes in photosynthetic oxygen evolution of Botryococcus braunii at different intensities and durations of UV-B treatment

\begin{tabular}{|c|c|c|c|c|c|}
\hline \multirow[b]{2}{*}{ Intensities $\left(\mathrm{Wm}^{-2}\right)$} & \multirow[b]{2}{*}{ Control* (without UV-B treatment) } & \multicolumn{4}{|c|}{ Duration $(\mathrm{min})\left(\mu \mathrm{mol} \mathrm{O} \mathrm{O}_{2} \mathrm{mg}\right.$ chlorophyll $\left.\mathrm{l}^{-1} \mathrm{~h}^{-1}\right)$} \\
\hline & & 15 & 30 & 45 & 60 \\
\hline 1 & $159 \pm 2.07$ & $155 \pm 2.07$ & $135 \pm 0.69$ & $95 \pm 2.76$ & $82 \pm 2.21$ \\
\hline 5 & $167 \pm 3.50$ & $117 \pm 0.69$ & $69 \pm 2.10$ & $46 \pm 2.00$ & $45 \pm 1.38$ \\
\hline
\end{tabular}

*Freshly sub-cultured.

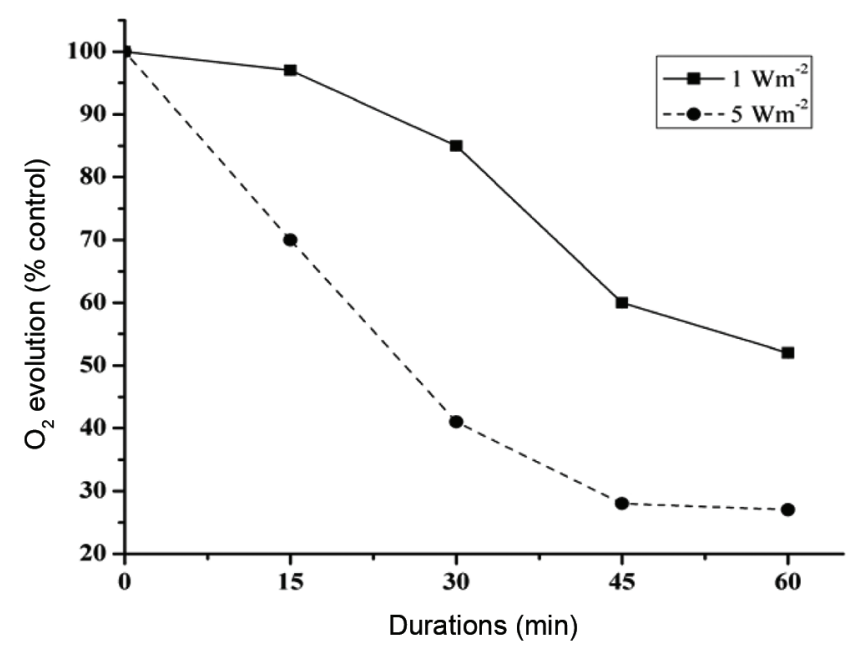

Figure 1. Changes in photosynthetic $\mathrm{O}_{2}$ evolution of Botryococcus braunii after UV-B treatment with respect to percentage activity of control at different intensities and durations.

control and UV-B treated B. braunii. Table 1 shows that oxygen evolution reduced to a minimum of $3 \%$ at $1 \mathrm{Wm}^{-2}$ in 15 min-treated cultures and maximum reduction of $49 \%$ and $73 \%$ was recorded at $60 \mathrm{~min}$ for 1 and $5 \mathrm{Wm}^{-2}$ treatments respectively. The short duration of treatment to high UV-B dose is more damaging than long periods of exposure at low irradiance $e^{27,28}$. The present study shows that UV-B radiation produces differential rate of inhibition in photosynthetic activity. However, such loss in photosynthetic activity with a reduction of $50 \%$ shows the severity of damage. Thus, the amount of exposure to UV-B can determine the severity of damage to the microalga. This implies that UV-B primarily attacks the photosynthetic reaction centre components ${ }^{29}$.

Growth measurements in terms of biomolecules are helpful in calculating possible changes, since growth is taken as an important factor that indicates the influence of stress in biochemical process within the primary producers. Therefore, in the present study other parameters, namely biomass, chlorophyll $a$ and metabolites, including total carotenoid, protein, carbohydrate and lipid were analysed over a specified time interval.

\section{$U V-B$ radiation and growth rate}

A study of the short-term effect of UV-B radiation stress on growth rate of $B$. braunii under different treatment conditions revealed the following results. The alga exhi- bited highly reduced growth rate when the doubling time of $B$. braunii was studied under $5 \mathrm{Wm}^{-2} \mathrm{UV}-\mathrm{B}$ treatment compared to $1 \mathrm{Wm}^{-2}$ (Table 2). From Table 2 doubling time of 2.19 days could be observed under control growth conditions; however, in UV-B treated $B$. braunii at $1 \mathrm{Wm}^{-2}$ for $15 \mathrm{~min}$ doubling time increased to 2.13 days. Comparatively, the doubling time has highly abridged at $5 \mathrm{Wm}^{-2} \mathrm{UV}-\mathrm{B}$ treatment studied, except at 15 min duration having a value of 2.45 days; rather it has increased to $4.68,5.35$ and 7.62 days at successive increased durations of 30,45 and $60 \mathrm{~min}$ respectively, showing severity of damage caused. Microalgae contribute up to $45 \%$ of the annual total global primary productivity and thus fix carbon dioxide into organic matter ${ }^{30}$. Thus the reduced growth rate will cause reduced atmospheric $\mathrm{CO}_{2}$ fixation. From the results it is clear that increased UV-B radiation imposes reduced growth rate, thereby indirectly reducing $\mathrm{CO}_{2}$ fixation rate. This will eventually lead to an increase in global warming and make the earth uninhabitable.

\section{$U V-B$ radiation and biomass production}

The biomass yield also showed gradual decrement with an increased intensity of UV-B treatment (Figure 2). On the 18th day control culture showed a high biomass content of $0.97 \mathrm{~g} \mathrm{l}^{-1}$ dry wt which was comparatively similar to earlier report ${ }^{31}$ having a biomass of $1 \mathrm{~g} \mathrm{l}^{-1}$ on 25 th day. UV-B treatment at $1 \mathrm{Wm}^{-2}$ for 15 min showed a biomass of $0.57 \pm 0.03 \mathrm{~g} \mathrm{l}^{-1}$ dry wt which was $19 \%$ less than control $\left(0.70 \pm 0.07 \mathrm{~g} \mathrm{l}^{-1}\right.$ dry wt) on the 15 th day. It further decreased by $56 \%\left(0.31 \pm 0.04 \mathrm{~g} \mathrm{l}^{-1}\right.$ dry wt) for $60-\mathrm{min}$ treated culture on 15 th day at the same intensity studied (Figure $2 a$ ). Similarly, treatment at a minimum duration of $15 \mathrm{~min}$ at $5 \mathrm{Wm}^{-2} \mathrm{UV}-\mathrm{B}$ radiation showed a decrement of $46 \% \quad\left(0.38 \pm 0.05 \mathrm{~g} \mathrm{l}^{-1}\right.$ dry wt $)$ on the 15 th day. Likewise, treatment for 30, 45 and $60 \mathrm{~min}$ duration at $5 \mathrm{Wm}^{-2}$ showed the rate of biomass decrement as $75 \%$ $\left(0.18 \pm 0.04 \mathrm{~g} \mathrm{l}^{-1}\right.$ dry wt $), 75 \%\left(0.18 \pm 0.02 \mathrm{~g} \mathrm{l}^{-1}\right.$ dry wt $)$ and $78 \%\left(0.16 \pm 0.04 \mathrm{~g} \mathrm{l}^{-1}\right.$ dry wt $)$ respectively, on the 15 th day (Figure $2 b$ ). Similarly, stunted growth rate of diatom Malosira nummoloidas under different doses of $\mathrm{UV}-\mathrm{B}$ radiation has been reported ${ }^{32}$.

\section{$U V-B$ radiation and photosynthetic pigment}

Immediately after $1 \mathrm{Wm}^{-2} \mathrm{UV}-\mathrm{B}$ treatment for $60 \mathrm{~min}$ duration, the concentration of chlorophyll $a$ decreased by 
Table 2. Doubling time of B. braunii under UV-B treated condition

\begin{tabular}{|c|c|c|c|c|c|}
\hline \multirow[b]{2}{*}{ UV-B intensity $\left(\mathrm{Wm}^{-2}\right)$} & \multirow[b]{2}{*}{ Control } & \multicolumn{4}{|c|}{ Doubling time (day) } \\
\hline & & $15 \mathrm{~min}$ & $30 \mathrm{~min}$ & $45 \min$ & $60 \mathrm{~min}$ \\
\hline 1 & 2.19 & 2.13 & 2.33 & 2.55 & 2.29 \\
\hline 5 & & 2.45 & 4.68 & 5.35 & 7.62 \\
\hline
\end{tabular}
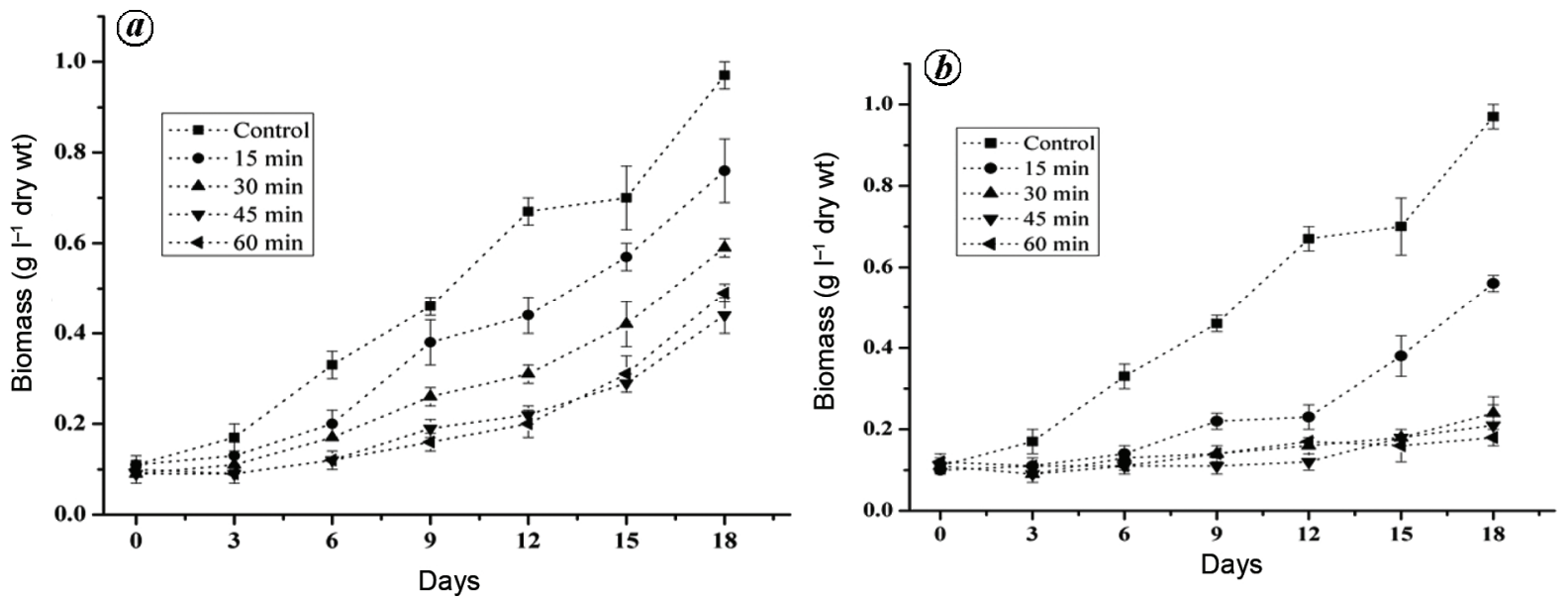

Figure 2. Effect of (a) $1 \mathrm{Wm}^{-2}$ and (b) $5 \mathrm{Wm}^{-2} \mathrm{UV}-\mathrm{B}$ on biomass of B. braunii.
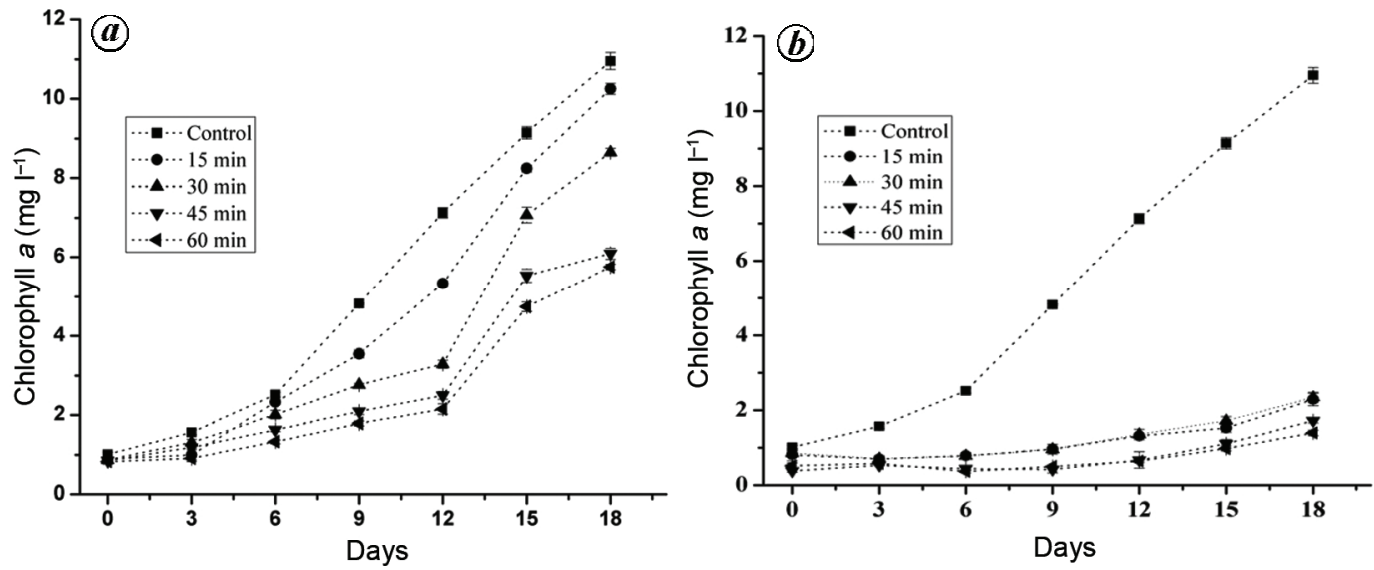

Figure 3. Effect of (a) $1 \mathrm{Wm}^{-2}$ and (b) $5 \mathrm{Wm}^{-2} \mathrm{UV}-\mathrm{B}$ on chlorophyll $a$ of $B$. braunii.

$18 \%\left(0.83 \pm 0.03 \mathrm{mg} \mathrm{l}^{-1}\right)$ than control $\left(1.01 \pm 0.05 \mathrm{mg} \mathrm{l}^{-1}\right)$. On the 15th day, decrement raised to $49 \%$ (4.74 \pm $0.12 \mathrm{mg} \mathrm{l}^{-1}$ ) than control $\left(9.14 \pm 0.15 \mathrm{mg} \mathrm{l}^{-1}\right.$ ) (Figure $3 a$ ). Whereas for alga treated for 15 and 60 min duration at $5 \mathrm{Wm}^{-2}$, chlorophyll $a$ concentration decreased by $84 \%$ $\left(1.52 \pm 0.11 \mathrm{mg} \mathrm{l}^{-1}\right) \quad$ and $90 \% \quad\left(0.98 \pm 0.07 \mathrm{mg} \mathrm{l}^{-1}\right)$ respectively, on the 15 th day compared to control $\left(9.14 \pm 0.15 \mathrm{mg} \mathrm{l}^{-1}\right)$ (Figure $\left.3 b\right)$. The decreased chlorophyll $a$ concentration directly shows pigment bleaching effect caused due to UV-B radiation stress ${ }^{33}$. In contrast to chlorophyll $a$, the concentration of total carotenoid decreased by only $32 \%\left(2.22 \pm 0.03 \mathrm{mg} \mathrm{l}^{-1}\right)$ at $1 \mathrm{Wm}^{-2}$ for $60 \mathrm{~min}$ of UV-B-treated culture on the 15 th day (Figure
$4 a$ ). However, the culture treated for $60 \mathrm{~min}$ at $5 \mathrm{Wm}^{-2}$ showed a decrease of $80 \%\left(0.65 \pm 0.04 \mathrm{mg} \mathrm{l}^{-1}\right)$ on the 15 th day than control $\left(3.22 \pm 0.11 \mathrm{mg} \mathrm{l}^{-1}\right.$ ) (Figure $4 \mathrm{~b}$ ). The results of photosynthetic pigment level towards UV$B$ radiation showed a high reduction of chlorophyll level than the other light harvesting carotenoids. As carotenoids are known to play a photoprotection role against photooxidation caused by abiotic stress, the level of carotenoids increases to protect against damage ${ }^{34}$. Less inhibition of carotenoids than chlorophylls by UV-B radiation was observed due to antioxidant property of the former, which neutralizes the singlet state of oxygen produced and mitigates the adverse effect of UV-B radiation. 
Table 3. $\mathrm{LD}_{50}$ percentage values of B. braunii under different UV-B treated condition on 15 th day

\begin{tabular}{|c|c|c|c|c|}
\hline \multirow[b]{2}{*}{ UV-B intensity $\left(\mathrm{Wm}^{-2}\right)$} & \multicolumn{4}{|c|}{$\begin{array}{c}\mathrm{LD}_{50}(\text { reduction } \%) \\
\text { Durations }(\mathrm{min})\end{array}$} \\
\hline & 15 & 30 & 45 & 60 \\
\hline 1 & 9 & 22 & 39 & 48 \\
\hline 5 & 83 & 81 & 87 & 89 \\
\hline
\end{tabular}
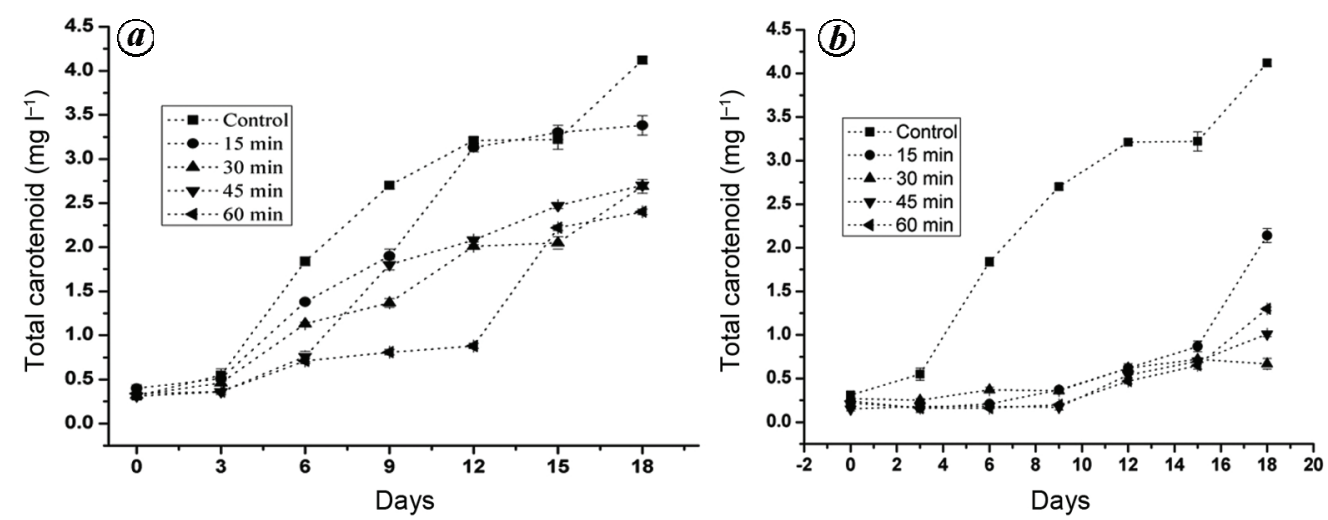

Figure 4. Effect of (a) $1 \mathrm{Wm}^{-2}$ and (b) $5 \mathrm{Wm}^{-2} \mathrm{UV}-\mathrm{B}$ on total carotenoid of B. braunii.
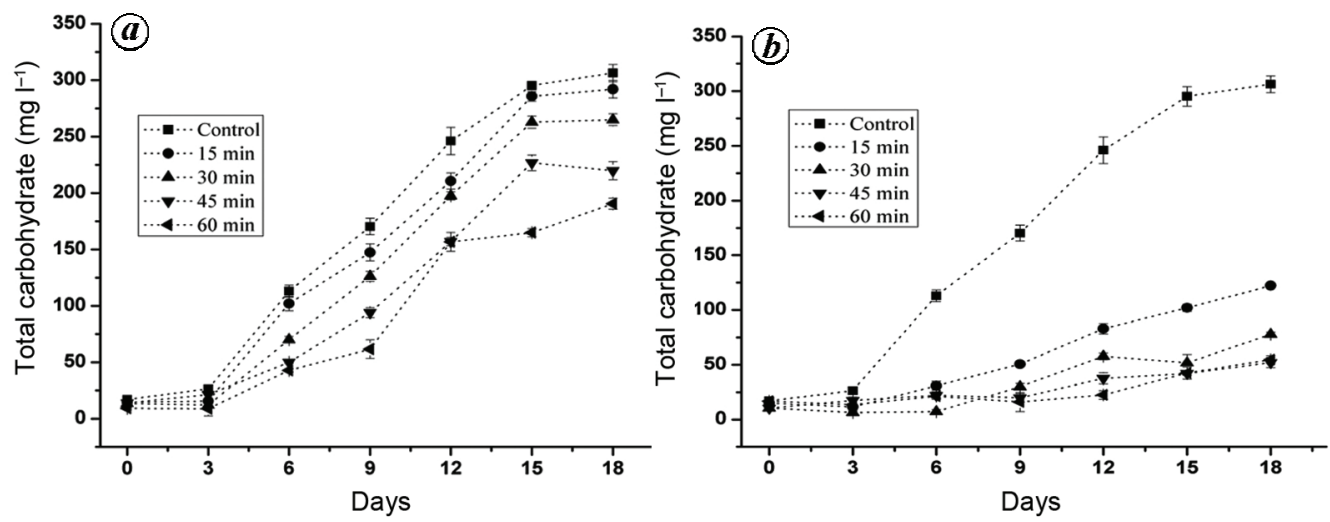

Figure 5. Effect of (a) $1 \mathrm{Wm}^{-2}$ and (b) $5 \mathrm{Wm}^{-2} \mathrm{UV}-\mathrm{B}$ on total carbohydrate of B. braunii.

The reduction in chlorophyll after being exposed to only $5 \mathrm{~h}$ per day of UV-B radiation, as reported by $\mathrm{Wu}$ et $a l .{ }^{35}$, was due to the differences in UV-B intensity ${ }^{35}$ (which is in contrast to the present study).

\section{$U V-B$ radiation and primary metabolites accumulation}

The primary metabolites, namely total carbohydrate, protein and lipid levels after UV-B treatment were also concurrently estimated. The total carbohydrate content was same as control $\left(295 \pm 3.54 \mathrm{mg} \mathrm{l}^{-1}\right)$ at $1 \mathrm{Wm}^{-2}$ for $15 \mathrm{~min}$ UV-B-treated cultures $\left(285 \pm 4.28 \mathrm{mg} \mathrm{l}^{-1}\right)$ on the 15 th day. However, 60 min-treated cultures at the same intensity showed $45 \%$ decrement $\left(164.92 \pm 3.57 \mathrm{mg} \mathrm{l}^{-1}\right)$ (Figure $5 a$ ). However, UV-B treatment at $5 \mathrm{Wm}^{-2}$ showed a highly reduced carbohydrate accumulation (Figure $5 b$ ).
The protein level was also altered with a reduction of $57 \%\left(55.02 \pm 2.11 \mathrm{mg} \mathrm{l}^{-1}\right)$ and $79 \%\left(28.76 \pm 2.88 \mathrm{mg} \mathrm{l}^{-1}\right)$ at 1 and $5 \mathrm{Wm}^{-2}$ on the 15 th day respectively, at the same duration of $60 \mathrm{~min}$ for UV-B treated cultures compared to control $\left(132.36 \pm 4.53 \mathrm{mg} \mathrm{l}^{-1}\right.$ ) (Figure $6 a$ and $b$ ). Thus the key enzymes and proteins are reported to be the direct targets of UV-B radiation ${ }^{36}$. As lipid peroxidation is oxidative degradation of lipid molecules, upon UV-B stress, B. braunii showed reduced growth rate due to cell damages, and therefore present lipid estimation result showed reduced lipid accumulation. There was a reduction of only $2 \%\left(162 \pm 4.20 \mathrm{mg} \mathrm{l}^{-1}\right)$ upon $1 \mathrm{Wm}^{-2} \mathrm{UV}-\mathrm{B}$ treatment for $15 \mathrm{~min}$ on the 15 th day, but a high reduction of $45 \%\left(91.52 \pm 3.49 \mathrm{mg} \mathrm{l}^{-1}\right)$ was recorded at $1 \mathrm{Wm}^{-2}$ on the 15 th day compared to control $\left(164.57 \pm 4.07 \mathrm{mg}^{-1}\right)$ (Figure $7 a$ ). At $5 \mathrm{Wm}^{-2}$ with minimum and maximum durations of 15 and 60 min UV-B treated cultures having 

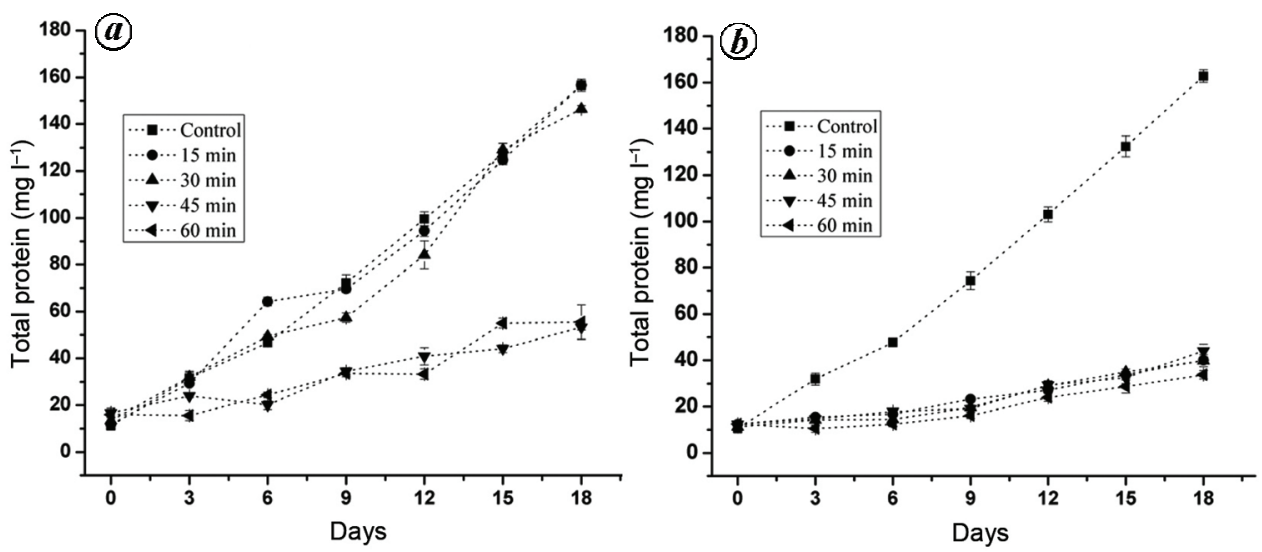

Figure 6. Effect of (a) $1 \mathrm{Wm}^{-2}$ and (b) $5 \mathrm{Wm}^{-2} \mathrm{UV}-\mathrm{B}$ on total protein of B. braunii.
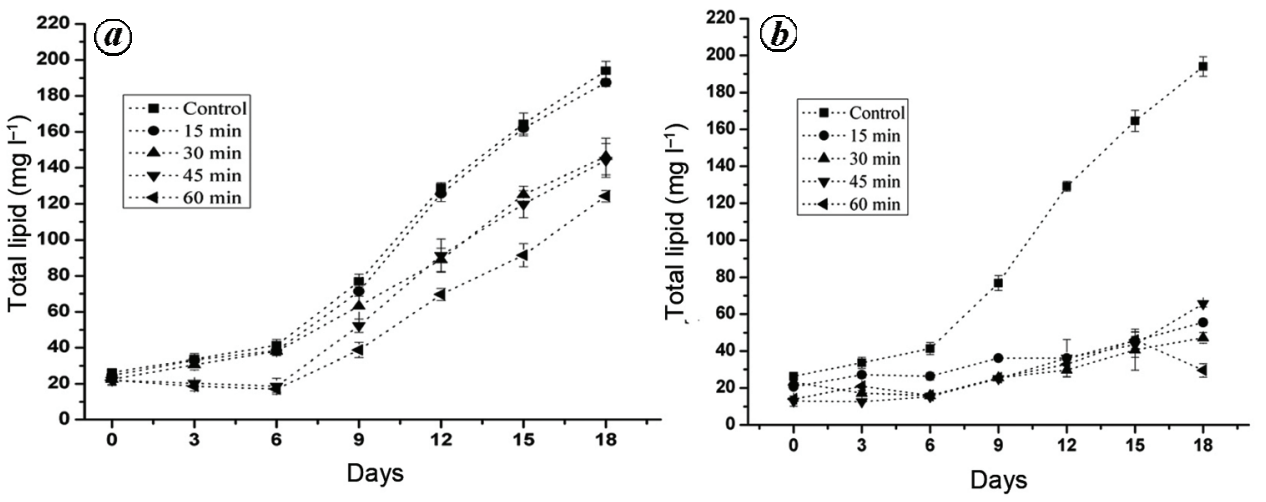

Figure 7. Effect of (a) $1 \mathrm{Wm}^{-2}$ and (b) $5 \mathrm{Wm}^{-2} \mathrm{UV}-\mathrm{B}$ on total lipid of B. braunii.

lipid accumulation of $45.71 \pm 2.23$ and $46 \pm 4.49 \mathrm{mg}^{-1}$ respectively, both showed a high reduction rate of $73 \%$ on the 15th day (Figure $7 b$ ). Thus, UV-B radiation directly affects growth through destruction of proteins and lipids with a reduced supply of ATP due to damages imposed on photosynthetic apparatus ${ }^{37}$.

\section{$L D_{50}$ percentage determination}

Among the chlorophyll $a$ concentrations studied under different treatment conditions, $B$. braunii treated for $15 \mathrm{~min}$ at $1 \mathrm{Wm}^{-2}$ retained growth almost equal to control and the alga showed $\mathrm{LD}_{50}$ value at $60 \mathrm{~min}$ of $1 \mathrm{Wm}^{-2}$ UV-B treatment (Table 3 ). Treatments at and above $15 \mathrm{~min}$ at $5 \mathrm{Wm}^{-2}$ showed a high degree of damage with declined growth (Table 3 ), which is calculated from the chlorophyll $a$ level. The effect of UV-B radiation on algae depends upon intensity and duration of exposure ${ }^{38}$. This is well-depicted in the present study, as UV-B treatment showed detrimental effects upon increasing intensities and durations on B. braunii. Thus, increased duration of UV-B treatment has a large impact on various growth factors. A decrement in photosynthetic efficiency and biomolecules accumulation in response to UV-B treatment has been observed with increasing intensities and durations studied ${ }^{39,40}$.

\section{Conclusion}

It is important to study the effects of UV-B radiation on commercially important and highly resistant species of microalgae. B. braunii is well known for its biofuel applications and can also be exploited for pharmaceutical applications. The present study showed the negative effects of UV-B radiation on $B$. braunii. The alga was found to retain its growth to a certain level; thereafter any increase seemed to be highly lethal for its survival. Hence, it is important to save our earth from the harmful effects of UV-B radiation caused by human activities, which greatly affect the low level of the ecosystem.

Conflict of interest: The authors declare that they have no conflict of interest.

1. Vimalabai, C. P. M. and Kulandaivelu, G., Effects of prolonged UV-B enhanced fluorescent radiation on some marine microalgae. Biol. Plant., 2002, 45(3), 389-394.

2. Häder, D. P., Kumar, H. D., Smith, R. C. and Worrest, R. C., Effects of solar UV radiation on aquatic ecosystem and interactions with climate change. Photochem. Photobiol. Sci., 2007, 6, 267-285.

3. Zhou, W., Yin, K., Yuan, X. and Ning, X., Comparison of the effects of short-term UVB radiation exposure on phytoplankton photosynthesis in the temperate Changjiang and subtropical Zhujiang estuaries of China. J. Oceanogr., 2009, 65(5), 627-638. 
4. Holzinger, A. and Lütz, C., Algae and UV irradiation: effects on ultrastructure and related metabolic functions. Micron, 2006, 37, 190-207.

5. Coohill, T. P., Ultraviolet action spectra (280 to $380 \mathrm{~nm})$ and solar effectiveness spectra for higher plants. J. Photochem. Photobiol., 1989, 50(4), 451-457.

6. Frederick, J. E., Ultraviolet sunlight reaching the earth's surface: a review of recent research. J. Photochem. Photobiol., 1993, 57, 175-178.

7. Hollosy, F., Effects of ultraviolet radiation on plant cell. Micron, 2002, 33, 179-197.

8. Hideg, E. and Vass, I., UV-B induced free radical production in plant leaves and isolated thylakoid membranes. Plant Sci., 1996, 115, 251-260.

9. Laurion, I. and Roy, S., Growth and photoprotection in three dinoflagellates (including two strains of Alexandrium tamarense) and one diatom exposed to four weeks of natural and enhanced ultraviolet-B radiation. J. Phycol., 2009, 45, 16-33.

10. Rastogi, R. P., Richa, Sinha, R. P., Singh, S. P. and Häder, D. P., Photoprotective compounds from marine organisms. J. Ind. Microbiol. Biotechnol., 2010, 37, 537-558.

11. Caldwell, M. M., Robberecht, R., Nowak, R. S. and Billings, W. D., Differential photosynthetic inhibition by ultraviolet radiation in species from the arctic-alpine life zone. Arct. Alp. Res., 1982, 14, 195-202.

12. Barnes, P. W., Flint, S. D. and Caldwell, M. M., Photosynthesis damage and protective pigments in plants from a latitudinal arctic/ alpine gradient exposed to supplemental UV-B radiation in the field. Arct. Alp. Res., 1987, 19, 21-27.

13. Banerjee, A., Sharma, R., Chisti, Y. and Banerjee, U. C., Botryococcus braunii: a renewable source of hydrocarbons and other chemicals. Crit. Rev. Biotechnol., 2002, 22(3), 245-279.

14. Metzger, P. and Largeau, C., Botryococcus braunii: a rich source for hydrocarbons and related ether lipids. Appl. Microbiol. Biotechnol., 2005, 66(5), 486-496.

15. Ranga Rao, A., Ravishankar, G. and Sarada, G., Cultivation of green alga Botryococcus braunii in raceway, circular ponds under outdoor conditions and its growth, hydrocarbon production. Bioresour. Technol., 2012, 123, 528-533.

16. Ranga Rao, A., Sarada, G. and Ravishankar, G., Enhancement of carotenoids in green alga Botyrocccus braunii in various autotrophic media under stress conditions. Int. J. Biomed. Pharm. Sci., 2010, 4(2), 87-92.

17. Yamaguchi, K. et al., Lipid composition of a green alga Botryococcus braunii. Agric. Biol. Chem., 1987, 57, 493-498.

18. Kumar, H. D., Effects of radiation on blue green algae. Ann. Bot., 1963, 27, 723-733.

19. Levasseur, M., Thompson, P. A. and Harrison, P. J., Physiological acclimation of marine phytoplankton to different nitrogen sources. J. Phycol., 1993, 29, 587-595.

20. Lichtenthaler, H. K., Chlorophyll's and carotenoids: pigments of photosynthetic biomembranes. In Methods in Enzymology (ed. Packer, L.), Academic Press, New York, USA, 1987, pp. 350 382 .

21. Dubois, M., Gilles, K. A., Hamilton, J. K., Rebers, P. A. and Smith, F., Colorimetric method for determination of sugars and related substances. Anal. Chem., 1956, 28, 350-356.

22. Bradford, M. M., A rapid and sensitive method for the quantitation of microgram quantities of protein utilizing the principle of protein dye binding. Anal. Biochem., 1976, 72, 248-254.

23. Folch, J., Lees, M. and Sloane-Stanley, G. H., A simple method for the isolation and purification of total lipids from animal tissues. J. Biol. Chem., 1957, 226, 497-509.
24. Ashokkumar, V. and Rengasamy, R., Mass culture of Botryococcus braunii Kutz. under open raceway pond for biofuel production. Bioresour. Technol., 2012, 104, 394-399.

25. Dayananda, C., Kumudha, A., Sarada, R. and Ravishankar, G. A., Isolation, characterization and outdoor cultivation of green microalgae Botryococcus sp. Sci. Res. Essays, 2010, 5(17), 2497-2505.

26. Dayananda, C., Sarada, R., Kumar, V. and Ravishankar, G., Isolation and characterization of hydrocarbon producing green alga Botryococcus braunii from Indian freshwater bodies. J. Biotechnol., 2007, 10(1), 78-91.

27. Cullen, J. J. and Lesser, M. P., Inhibition of photosynthesis by ultraviolet radiation as a function of dose and dosage rate: results for a marine diatom. Mar. Biol., 1991, 111, 183-190.

28. Latha Prabha, G. and Kulandaivelu, G., Induced UV-B resistance against photosynthesis damage by adaptive mutagenesis in Synechococcus PCC 7942. Plant Sci., 2002, 162, 663-669.

29. Noorudeen, A. M. and Kulandaivelu, G., On the possible site of inhibition of photosynthetic electron transport by ultraviolet-B (UV-B) radiation. Physiol. Plant, 1982, 55, 161-166.

30. Longhurst, A. R., Role of the marine biosphere in the global carbon cycle. Limnol. Oceanogr., 1991, 36(8), 1507-1526.

31. Ranga Rao, A., Sarada, R. and Ravishankar, G. A., Influence of $\mathrm{CO}_{2}$ on growth and hydrocarbon production in Botryococcus braunii. J. Microbiol. Biotechnol., 2007, 17(3), 414-419.

32. Thompson, B. E., Worrest, R. C. and Van Dyke, H., The growth response of estuarine diatom (Melosira nummuloides (Dilw.) Ag.) to UV-B (290-320 nm) radiation. Estuaries, 1980, 3, 69-72.

33. Häder, D. P., Rhiel, E. and Wehrmeyer, W., Ecological consequences of photo-movement and photobleaching in the marine flagellate Cryptomonas maculate. FEMS Microbiol. Ecol., 1988, 53, 9-18.

34. Havaux, M., Carotenoid oxidation products as stress signals in plants. Plant J., 2013, 79, 597-606.

35. Wu, H., Gao, K., Villafane, V. E., Watanabe, T. and Helbling, E. W., Effects of solar UV radiation on morphology and photosynthesis of filamentous cyanobacterium Arthrospira platensis. Appl. Environ. Microbiol., 2005, 7(9), 5004-5013.

36. Döhler, G., Effect of UV-B radiation on biomass production, pigmentation and protein content of marine diatoms. Z. Naturforch., 1984, 39, 634-638.

37. Kulandaivelu, G. and Noorudeen, A. M., Comparative study of the action of ultraviolet-C and ultraviolet-B radiation in photosynthetic electron transport. Physiol. Plant., 1983, 58, 389-394.

38. Rai, L. C. and Mallick, N., Algal responses to enhanced ultraviolet B radiation. Proc. Natl. Acad. Sci. USA, 1998, B64, 125-146.

39. Villafañe, E. V., Sundbäck, K., Figueroa, F. L. and Helbling, E. W., Photosynthesis in the aquatic environment as affected by UVR. In UV Effects in Aquatic Organisms and Ecosystems (eds Helbling, W. and Zagarese, H.), The Royal Society of Chemistry, Cambridge, UK, 2003, pp. 357-397.

40. Wong, C., Teoh, M. L., Phang, S. M., Lim, P. E. and Beardall, J., Interactive effects of temperature and UV radiation on photosynthesis of Chlorella strains from polar, temperate and tropical environments: differential impacts on damage and repair. PLOS ONE, 2015, 10(10), e0139469; doi:10.1371/journal.pone.0139469.

ACKNOWLEDGEMENTS. We thank the Centre for Advanced Studies in Botany, University of Madras, Chennai, for providing the algal strains, and DST, New Delhi for financial assistance.

Received 18 October 2017; revised accepted 16 August 2018

doi: $10.18520 / \mathrm{cs} / \mathrm{v} 116 / \mathrm{i} 1 / 89-95$ 